\title{
Examination of football players' perfectionism features and subjective stress perceptions
}

\author{
Çağrı Hamdi ERDOGAN ${ }^{1}$, Ramazan TOPUZ², Ziya BAHADIR ${ }^{3}$ \\ ${ }^{1}$ Erciyes University, Department of Sports Sciences, PhD Student. \\ ${ }^{2}$ Selçuk University, Faculty of Sport Sciences, Academic Member. \\ ${ }^{3}$ Erciyes University, Faculty of Sport Sciences, Academic Member. \\ Address Correspondence to ÇH. Erdoğan e-mail: erdoganhamdi@hotmail.com
}

\begin{abstract}
The aim of this study is to determine the perfectionism characteristics and subjective stress perceptions of football players. In this respect, subjective stress perceptions and perfectionism characteristics of football players were examined according to variables such as age, marital status, educational level, income level, football background and position. The research was conducted with the descriptive survey model. Randomly selected 279 amateur football players, who actively played football in the super group and the first group during the 2017-2018 seasons in Konya province, participated in the study. "Multidimensional Perfectionism Scale" and "Perceived Stress Scale" were used as the data collection tools. SPSS program was used in the analysis of the data. According to the results of the research, subjective stress perceptions and perfectionism features of the football players were determined as "midlevel". In addition, a negative significant relationship was found between the football players' perfectionism features and subjective stress perception. Perfectionism features of the football players significantly differed based on their football backgrounds, gender, age, educational level, income level and the position they played. Subjective stress perceptions of them did not show any significant difference concerning gender, age, educational level, income level, football background and position.
\end{abstract}

Keyword: Football, Perfectionism, Stress

\section{INTRODUCTION}

The perception of dissatisfaction with oneself when an individual is worried that the products he/she produces are not good enough, and when he/she is not happy at all in performance is called perfectionism (30). Perfectionism is to determine high standards for oneself and others and to try to preserve these standards (26).

According to Horney (19), perfectionism is the pathological adaptation to the conditions of a person's self-alienation. Frost et al. (14) have described perfectionism as an excessive criticism and tendency to create extremely high standards for self-assessment.
According to Hollander (18); perfectionism expects higher performance from oneself and others. Frost et al. (14) define the perfectionism in the way that the person determines the standards above his/her performance and does not tolerate the thought of inability to reach this desire.

Perfectionism is divided into two parts as internal and external perfectionism. Internal perfectionism is the effort related to a strong motivation to be perfect, creating unrealistic individual rules and etc. External perfectionism is the situation where these behaviors displayed otherorientedly, not in a self-oriented manner (29). 
It is known that environmental factors and family behaviors and parental attitudes have a crucial role in creating and sustaining perfection levels of people (32). Perfectionism has become a difficult lifestyle that is hard to change because it takes place in people's lives, so it is thought to be a built-in feature (34).

In perfectionism, setting very high standards for oneself and the effort to reach these standards has caused the person to have a negative and rigid attitude towards himself (6). Rimm (27) states that there is no room for error in the structure of perfectionism and that such people always want to achieve the best result.

Adler (3) considered perfectionism as a normal and innate feature, dealing with it in two dimensions, healthy and unhealthy. Roedell (28) states that perfectionism has positive and negative dimensions and when people determine high standards on them perfectionism can be a great energy that brings success.

Stress is a condition that occurs by threatening and forcing the organism's physical and mental limits (15). In other words, it is defined as "the interaction between the person and the environment, which puts the person's well-being in jeopardy, which evaluates the capacity as reducing and compelling" (16).

Stress is a distress or strain that is felt as the consequences of the pressures of human relations in everyday life (24). Stress is also a process that leads to psychological and biological changes in the organism, when the organism exceeds the capacity of adaptation to the expectations of the environment (1).

Stress occurs as a result of person and environment interaction. What is important in this interaction is that the individuals may perceive and evaluate events and people as a source of stress. In this interaction, people will not get stressed if they do not consider the events and people around them as a source of stress (9).
Stress affects the individual's life and functionality in a negative way, and being exposed to a long-term stress causes various health problems and poor life quality (13). Reaction to the stress can lead to the emergence of headaches, high blood pressure, heart problems or psychological and mental illnesses in the long term. The development process of chronic diseases can be related to the intensity and frequency of stress (5)

The objective of football is to win, which is inherent to all branches of sports, and which has different results in every sense. Stress can also be considered as one of them. Football players are stressed by many factors such as ambition to win, fanfare, coach influence, referee attitude, behavior of opponent players, and even the weather. Moreover, if the football players have the perfectionist personality characteristics, it can influence this stress situation, as well. In this regard, stress and perfectionism levels of players have really aroused curiosity in the scientific sense and considered important.

The main purpose of this research is to determine the perfectionism features of football players and their subjective stress perceptions. In addition, stress and perfectionism features of football players are examined according to age, marital status, educational level, income level, football background and position variables.

\section{MATERIALS \& METHODS}

\section{Research Model}

This research study was conducted as a descriptive survey model, examining the perfectionism characteristics and subjective stress perceptions of football players. Survey models are a research approach that attempts to address the past or present as it is (21).

\section{Research Group}

The research group is comprised of randomly selected 279 amateur football players, who actively play football in the super group and the first group in Konya province during the 2017-2018 season. 110 
(39.4\%) of the football players participating in the research were between 17-21 years old, while 96 (34.4\%) of them were between $22-26$ years old, while $47(16.8 \%)$ of them were between 27-31, and 26 (9, $3 \%$ ) were between 32-36 years old.

\section{Data Collection Tools}

To determine the demographic characteristics of the players in the study, "Personal Information Form" was used, in order to determine the perfectionism traits "Multidimensional Perfectionism Scale" was used, and to determine the subjective stress perception "Perceived Stress Scale" was used as data collection tools. The Personal Information Form was prepared by the researchers, considering the expert opinion and similar research studies in the literature.

The Multidimensional Perfectionism Scale was developed by Hewitt and Flett (17) to measure adult perfectionist personality traits. There are 45 items on the scale and the items are scored in a seven-point Likert-type ( $1=$ strongly disagree, $7=$ strongly agree). The total score of the scale ranges between 44 and 308, and the higher the score the higher the perfectionist personality. Studies of adaptation of the scale to Turkish were conducted by Oral (25). As a result of factor analysis, it was observed that three factors accounted for $37.5 \%$ of the total variance. The Cronbach Alpha internal coefficient of consistency of the scale was found to be .91 for the "self-directed perfectionism" subscale, .80 for the "perfectionism for the others" subscale, and .73 for the "communityimposed perfectionism" subscale. The item totalcorrelation coefficients for the subscales ranged from .20 to .75 for the 'self-directed perfectionism' subscale, from .22 to .60 for the 'perfectionism towards others' subscale, from .31 to .52 for the 'community-imposed perfectionism' subscale.
The Perceived Stress Scale was developed by Cohen et al. (8) to measure stress perceptions of individuals. The Perceived Stress Scale is a fivepoint Likert-type scale consisting of 14 items. Participants evaluate each item between 0 and 4 (Never-0, and Very Often-4). 7 of the items are scored inversely. The total scores from the scale range from 0 to 56 . The high score on the scale indicates that the person's stress perception is above normal. Perceived Stress Scale was translated into Turkish by Baltaş et al. (4). Baltaş et al. (4) reported that the internal consistency coefficient of the scale was calculated as .84 and the test-repeat-test reliability coefficient was calculated as .87 .

\section{Analysis of Data}

SPSS program was used for statistical analysis. Arithmetic mean $(\overline{\mathrm{X}})$ and standard deviation (Sd) techniques were used for descriptive statistics to investigate the perfectionism features and subjective stress perceptions of football players. According to Kolmogorov-Smirnov Test results, the perfectionist characteristics of football players showed a normal distribution $(p=.200)$, and subjective stress perceptions showed anomalous distribution $(p=.007)$. The Mann-Whitney $U$ test was used in dual comparisons and the Kruskall Wallis $\mathrm{H}$ Test in multiple comparisons to assess the abnormal distribution of subjective stress perceptions of football players. In order to evaluate the normalized distribution of perfectionist features of football players, Independent-Samples $\mathrm{T}$ Test was used in dual comparisons and One Way ANOVA techniques were used in multiple comparisons. When the significance $(\mathrm{p})$ levels were interpreted, $\mathrm{p}$ $<0.05$ was taken as the criterion. Pearson Correlation analysis technique was also used for relationship measurement. 


\section{FINDINGS}

Table 1. Distributions by demographical characteristics of football players in the research group

\begin{tabular}{llllll}
\hline Age & $\mathrm{N}$ & $\%$ & Monthly earnings & $\mathrm{N}$ & $\%$ \\
\hline $17-21$ & 110 & 39.4 & Low & 54 & 19.4 \\
$22-26$ & 96 & 34.4 & Mid & 189 & 67.7 \\
$27-31$ & 47 & 16.8 & High & 36 & 12.9 \\
$32-36$ & 26 & 9.3 & & & \\
\hline & & & & & \\
\hline Marital status & $\mathrm{N}$ & $\%$ & Football background & $\mathrm{N}$ & $\%$ \\
\hline Married & 45 & 16.1 & 1-5 Years & 105 & 37.6 \\
Single & 234 & 83.9 & 6-10 Years & 108 & 38.7 \\
& & & $11-15$ Years & 66 & 23.7 \\
\hline & & & & $\mathrm{N}$ & $\%$ \\
\hline Educational level & $\mathrm{N}$ & $\%$ & Position & 91 & 32.6 \\
\hline Secondary School & 74 & 26.5 & Back & 124 & 44.4 \\
High School & 142 & 50.9 & Midfield & 64 & 22.9 \\
University & 63 & 22.6 & Forward & & \\
\hline
\end{tabular}

$110(39.4 \%)$ of the football players participated in the research were between 17-21 years old, and 96 $(34.4 \%)$ were between 22-26 years old, while 47 $(16.8 \%(9,3 \%)$ were between $32-36$ years old. 45 (16, $1 \%)$ of the football players were married and 234 $(83,9 \%)$ were single. As per the educational levels, 74 $(26.5 \%)$ of the players were primary school graduates, while $142(50.9 \%)$ were secondary school graduates, and $63(22.6 \%)$ are high school graduates. When we look at monthly incomes, 54 (19.4\%) of the football plarsare low income, $189(67.7 \%)$ are middle income and $36(12.9 \%)$ are high income. $105(37,6 \%)$ f football players have for 1-5 years, $108(38,7 \%)$ have for $6-10$ years and $66(23,7 \%)$ have for $1-15$ years football background. When we look at the positions played by the players in the research group, it is seen that $91(32.6 \%)$ of the players are back, $124(44.4 \%)$ are midfield and $64(22.9 \%)$ are forward.

Table 2. Mean distribution of the football players in the study group according to multidimensional perfectionism scale and perceived stress scale

\begin{tabular}{lccc}
\hline Scale & $\mathrm{N}$ & $\overline{\mathrm{X}}$ & $\mathrm{Sd}$ \\
\hline Multidimensional perfectionism scale & 279 & 188.09 & 23.533 \\
\hline Perceived stress scale & 279 & 26.27 & 5.274 \\
\hline
\end{tabular}

When Table 2 was examined, it was observed that the football players, who participated in the research, had a mean of $\bar{X}=188.09$ from the Multidimensional Perfectionism Scale and $\bar{X}=26.27$ from the Perceived Stress Scale. When it was evaluated according to the minimum and maximum scores obtained from the scales, it was determined that the football players in the research group had the "midlevel" perfectionism features and "midlevel" stress perception. 
Table 3. The relationship between multidimensional perfectionism and perceived stress of the football players in the research group

\begin{tabular}{llcc}
\hline & & Perceived stress scale & Multidimensional perfectionism scale \\
\hline Perceived stress scale & Pearson correlation & 1 & $-0.141^{*}$ \\
\cline { 2 - 4 } & Sig. (2-tailed) & & 0.018 \\
\cline { 2 - 4 } & $\mathrm{N}$ & 279 & 279 \\
\hline \multirow{2}{*}{$\begin{array}{l}\text { Multidimensional perfectionism } \\
\text { scale }\end{array}$} & Pearson correlation & $-0.141^{*}$ & 1 \\
\cline { 2 - 4 } & Sig. (2-tailed) & .018 & 279 \\
\cline { 2 - 4 } & $\mathrm{N}$ & 279 & \\
\hline
\end{tabular}

When Table 3 was examined, a significant negative correlation $(\mathrm{r}=-, 141)$ was determined perceived stress of the football players in the research group $(\mathrm{p}<0.05)$. between the multidimensional perfectionism and

Table 4. The comparison of the means of the football players according to data obtained from the multidimensional perfectionism scale according to the variables

\begin{tabular}{|c|c|c|c|c|c|c|c|}
\hline & & $\mathrm{N}$ & $\bar{x}$ & Sd & $\mathrm{t}$ & $\mathrm{p}$ & Difference \\
\hline \multirow{2}{*}{ ¿্் } & Married & 45 & 187.00 & 28.810 & \multirow{2}{*}{-0.340} & \multirow{2}{*}{0.734} & \multirow{2}{*}{ No } \\
\hline & Single & 234 & 188.30 & 22.444 & & & \\
\hline & & $\mathrm{N}$ & $\bar{x}$ & $\mathrm{Sd}$ & $\mathrm{F}$ & $\mathrm{p}$ & Difference \\
\hline \multirow{5}{*}{$\underset{4}{8}$} & $17-21$ & 110 & 186.02 & 22.274 & \multirow[t]{4}{*}{0.539} & \multirow[t]{4}{*}{0.656} & \multirow{4}{*}{ No } \\
\hline & $22-26$ & 96 & 190.05 & 25.071 & & & \\
\hline & $27-31$ & 47 & 189.19 & 19.171 & & & \\
\hline & $32-36$ & 26 & 187.61 & 29.906 & & & \\
\hline & & $\mathrm{N}$ & $\bar{x}$ & Sd & $\mathrm{F}$ & $\mathrm{p}$ & Difference \\
\hline \multirow{5}{*}{ 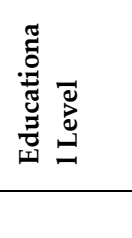 } & Secondary & 74 & 185.79 & 20.234 & \multirow{4}{*}{2.506} & \multirow{4}{*}{0.083} & \multirow{4}{*}{ No } \\
\hline & School & & & & & & \\
\hline & High School & 142 & 186.73 & 24.687 & & & \\
\hline & University & 63 & 193.85 & 23.892 & & & \\
\hline & & $\mathrm{N}$ & $\bar{x}$ & Sd & $\mathrm{F}$ & $\mathrm{p}$ & Difference \\
\hline \multirow{4}{*}{ 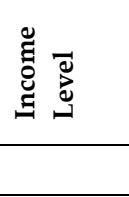 } & Low & 54 & 191.12 & 22.740 & \multirow{3}{*}{0.561} & \multirow{3}{*}{0.571} & \multirow{3}{*}{ No } \\
\hline & Mid & 189 & 187.29 & 23.406 & & & \\
\hline & High & 36 & 187.75 & 25.600 & & & \\
\hline & & $\mathrm{N}$ & $\bar{x}$ & $\mathrm{Sd}$ & $\mathrm{F}$ & $\mathrm{p}$ & Difference \\
\hline \multirow{4}{*}{ 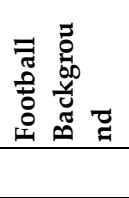 } & 1-5 Years & 105 & 190.10 & 23.265 & \multirow{3}{*}{3.652} & \multirow{3}{*}{$0.027^{*}$} & \multirow{3}{*}{$\begin{array}{l}\text { 1-5 Years }>11-15 \text { Years } \\
6-10 \text { Years }>11-15 \text { Years }\end{array}$} \\
\hline & 6-10 Years & 108 & 190.27 & 23.397 & & & \\
\hline & 11-15 Years & 66 & 181.31 & 23.247 & & & \\
\hline & & $\mathrm{N}$ & $\bar{x}$ & $\mathrm{Sd}$ & $\mathrm{F}$ & $\mathrm{p}$ & Difference \\
\hline \multirow{4}{*}{ : } & Back & 91 & 188.98 & 26.162 & \multirow{3}{*}{1.552} & \multirow{3}{*}{0.214} & \multirow{3}{*}{ No } \\
\hline & Midfield & 124 & 189.75 & 22.132 & & & \\
\hline & Forward & 64 & 183.59 & 21.965 & & & \\
\hline & Total & 279 & 188.09 & 23.533 & & & \\
\hline
\end{tabular}


When Table 4 was examined, while the perfectionism features of the football players in the research group showed a significant difference $(p$ $<0.05$ ) concerning their football background; there is no significant difference $(\mathrm{p}>0.05)$ concerning gender, age, educational level, income level, and position they played.

Table 5. Comparison of the means of the football players according to data obtained from the perceived stress scale according to some variables

\begin{tabular}{|c|c|c|c|c|c|c|c|}
\hline & & $\mathrm{N}$ & Mean Rank & Sum of Ranks & $\mathrm{U}$ & $\mathrm{p}$ & Difference \\
\hline \multirow{3}{*}{ 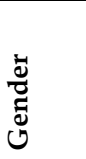 } & Married & 45 & 134.67 & 6060.00 & \multirow{3}{*}{5025} & \multirow{3}{*}{0.628} & \multirow{3}{*}{ No } \\
\hline & & & & & & & \\
\hline & Single & 234 & 141.03 & 33000.00 & & & \\
\hline & & $\mathrm{N}$ & Mean Rank & $\mathrm{df}$ & $\chi^{2}$ & $\mathrm{p}$ & Difference \\
\hline \multirow{5}{*}{$\underset{4}{\infty}$} & $17-21$ & 110 & 137.56 & 3 & \multirow{4}{*}{.721} & \multirow{4}{*}{0.868} & \multirow{4}{*}{ No } \\
\hline & $22-26$ & 96 & 143.40 & & & & \\
\hline & $27-31$ & 47 & 143.87 & & & & \\
\hline & $32-36$ & 26 & 130.79 & & & & \\
\hline & & $\mathrm{N}$ & Mean Rank & $\mathrm{df}$ & $\chi^{2}$ & $\mathrm{p}$ & Difference \\
\hline \multirow{5}{*}{ 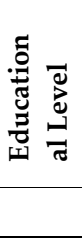 } & Secondary & 74 & 146.39 & 2 & \multirow{4}{*}{0.846} & \multirow{4}{*}{0.655} & \multirow{4}{*}{ No } \\
\hline & School & & & & & & \\
\hline & High School & 142 & 135.97 & & & & \\
\hline & University & 63 & 141.59 & & & & \\
\hline & & $\mathrm{N}$ & Mean Rank & $\mathrm{df}$ & $\chi^{2}$ & $\mathrm{p}$ & Difference \\
\hline \multirow{4}{*}{ 芯 } & Low & 54 & 141.71 & 2 & \multirow{3}{*}{0.053} & \multirow{3}{*}{0.974} & \multirow{3}{*}{ No } \\
\hline & Mid & 189 & 139.23 & & & & \\
\hline & High & 36 & 141.46 & & & & \\
\hline & & $\mathrm{N}$ & Mean Rank & $\mathrm{df}$ & $\chi^{2}$ & $\mathrm{p}$ & Difference \\
\hline \multirow{5}{*}{ 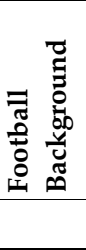 } & 1-5 Years & 105 & 144.98 & 2 & \multirow{4}{*}{.740} & \multirow{4}{*}{0.691} & \multirow{4}{*}{ No } \\
\hline & & & & & & & \\
\hline & 6-10 Years & 108 & 138.47 & & & & \\
\hline & 11-15 Years & 66 & 134.58 & & & & \\
\hline & & $\mathrm{N}$ & Mean Rank & $\mathrm{df}$ & $\chi^{2}$ & $\mathrm{p}$ & Difference \\
\hline \multirow{4}{*}{$\begin{array}{l}: 0 \\
\stackrel{D}{0} \\
0\end{array}$} & Back & 91 & 139.83 & 2 & \multirow{3}{*}{0.167} & \multirow{3}{*}{0.920} & \multirow{3}{*}{ No } \\
\hline & Midfield & 124 & 138.36 & & & & \\
\hline & Forward & 64 & 143.42 & & & & \\
\hline & Total & 279 & & & & & \\
\hline
\end{tabular}

When Table 5 was examined, the subjective stress perceptions of the football players in the study group did not demonstrate any significant

\section{CONCLUSIONS \& DISCUSSION}

As a result of the research, the subjective stress perceptions and perfectionism features of the Turk ل Spart Exe 2018; 20(3): 283- 291 ๑ 2018 Faculty of Spart Sciences, Selcuk University difference in terms of gender, age, educational level, income level, football background, and position they played ( $\mathrm{p}>0.05)$.

football players in the research group were determined as "midlevel". In addition, a significant and negative relationship was found between the 
football players' perfectionism features and subjective stress perception. The perfectionist features of the football players in the study group showed a significant difference concerning their football backgrounds; there was no significant difference in terms of gender, age, educational level, income level, and the position they played. The subjective stress perceptions of the football players in the research group did not show any significant difference in terms of gender, age, educational level, income level, football background, and position they played.

As a result of the research studies carried out by Uyanık (33), Karataş (22), Cesur (7) and Kızılöz Başsayın (23), it was determined that the perfectionism features of the participants was "midlevel", which was in parallel with the results of this research. Uyanik (33) did not find any significant difference between the participants' perfectionism features in terms of age and income level, which is similar with our research. According to Uyanık (33), a significant difference was found in perfectionism features; however, the results of our research did not match with these results. Abuhanoğlu et al. (2) found a significant difference between the perfectionism features of the participants in terms of gender variable in their research, and the findings of our research were contrary to this finding. Kalkan Dişbudak (20) found a significant difference among the participants' perfectionism features in terms of age and marital status; however, the results of our research were not in parallel with this research. Kalkan Dişbudak (20) did not find any significant difference in perfectionism features in terms of gender, which complied with our research. Cesur (7) did not find any significant difference among the perfectionism features in terms of age, marital status, educational status, and income level, and it is in parallel with our research results. Cesur (7), found a significant difference in perfectionism characteristics in terms of gender; however, the findings of our research were in contrary to these results.

Yıldız (35) identified participants' subjective stress perceptions as "midlevel", which complied with the results of our research. Doğaner (11) identified participants' subjective stress perceptions as "low level", which contradicted the results of our study. Ekiz (12) determined a significant difference in subjective stress perceptions in terms of gender, however, this result did not comply with those of our study. Taş (31) did not find significant differences in subjective stress perceptions of the participants in terms of gender, age, marital status, and educational level, and it was parallel to the results of our research.

The subjective stress perceptions and perfectionism characteristics of football players can be examined thoroughly via the qualitative research. The determination of the subjective stress perceptions and perfectionism characteristics of the football players in the study group as "midlevel" may be a guide for further qualitative research studies to be conducted in this field. Considering that all the football players in the research group are male, the results of the perfectionism characteristics and subjective stress perceptions in this research are thought to be impossible to generalize for all football players. The results of the research are informative if it is about male football players' perfectionism characteristics and subjective stress perception. A similar study can be conducted on female football players, or it can be carried out on the perfectionism characteristics and subjective stress perceptions of female football players. Factors such as determination to win, fan pressure, coach influence, and climate change can be shown as the reasons of the significant negative relationship between the perfectionism characteristics and subjective stress perceptions of the football players in the research group. Further research studies, in which these reasons are also evaluated, can be applied. The fact that the players with less football experience have higher perfectionism characteristics compared to the ones with more experience can be attributed to lack of experience; besides, a special study can be done to investigate this subject. It can be evaluated as a positive situation that the subjective stress perception and perfectionism characteristics of football players are not in high levels. An expert 
support can be provided on this subject to the football players by the sports psychologists.

\section{REFERENCES}

1. Abdel Wahed WY, Hassan SK. Prevalence and associated factors of stress, anxiety and depression among medical Fayoum University students, Alexandria Journal of Medicine, 2017; 53(1): 77-84.

2. Abuhanoğlu H, Teke A, Çelen Ö, Açıkel C. Sağlık insan gücü yetiştiren önlisans ve lisans düzeyindeki okullarda mükemmeliyetçilik, TAF Preventive Medicine Bulletin, 2015; 14(5); 413-423.

3. Adler A. The neurotic disposition, In H. L. Ansbacher \& R. R. Ansbacher (Eds.), The Individual Psychology of Alfred Adler, New York, Harper, 1956: 239-262.

4. Baltaş Z, Atakuman Y, Duman Y. Standardization of the perceived stress scale, perceived stress in middle managers, Stress and Anxiety Research Society 19 the International Conference, Boğaziçi University, İstanbul, July 10-12, 1998.

5. Baltaş A, Baltaş Z. Stres ve Başa Çıkma Yolları, Remzi Kitabevi, 2010: 85.

6. Campbell JD and DiPaula A. Perfectionist self-beliefs: their relation to personality and goal pursuit, Flett, G. L.,Hewitt, P. L. (ed.). Perfectionism: Theory, Research, and Treatment. Washington DC: American Psychological Association, 2002: 181-198.

7. Cesur C. Bir Grup Çalışan Yetişkinde Kaygı Düzeyi, Mükemmeliyetçilik ve Öfke Arasındaki İlişki (Yüksek Lisans Tezi), Işık Üniversitesi, Sosyal Bilimler Enstitüsü, Klinik Psikoloji Anabilim Dalı, 2017.

8. Cohen S, Kamarck T, Mermelstein R. A global measure of perceived stress, Journal of Health and Social Behavior, 1983; 24: $385-396$

9. Çakır İ. Polislerin İş Stresi ve Bazı Değişkenlere Göre Stresle Başa Çıkma Tarzlarının Karşılaştırılması (Yüksek Lisans Tezi), Çukurova Üniversitesi, Sosyal Bilimler Enstitüsü, Eğitim Bilimleri Anabilim Dalı, 2006.

10. Demirci E. Ergenlerde Temel Psikolojik İhtiyaçlar İrrasyonel İnanışları ile Mükemmeliyetçilik ve Sınav Kaygısı Arasındaki İlişki, (Yüksek Lisans Tezi), İstanbul Üniversitesi Sosyal Bilimler Enstitüsü, 2018.

11. Doğaner S. Düzenli Egzersiz Programının Bireylerin Stres, Mutluluk ve Serbest Zaman Doyum Düzeylerine Etkisi (Doktora Tezi), Ankara Üniversitesi, Sağlık Bilimleri Enstitüsü, Spor Bilimleri Anabilim Dalı, 2017.

12. Ekiz Ö. Spor ve Sağlık Alanlarında Öğrenim Gören Üniversite Öğrencilerinin Algılanmış Stres Seviyeleri ve Sağlıklı Yaşam Biçimi Davranışlarının İncelenmesi Kahramanmaraş İli Örneği (Yüksek Lisans Tezi),
Kahramanmaraş Sütçü İmam Üniversitesi, Sağlık Bilimleri Enstitüsü, Beden Eğitimi ve Spor Anabilim Dalı, 2016.

13. Eskin M, Harlak H, Demirkıran F and Dereboy Ç. Algılanan stres ölçeğinin türkçeye uyarlanması: güvenirlik ve geçerlik analizi. In New/Yeni Symposium Journal, 2013; 51(3): 132-140.

14. Frost RO, Marten P, Lahart C, Rosenblate R. The dimensions of perfectionism, Cognitive Therapy and Research, 1990; 14: $449-468$.

15. Gibbons, C. Hea stem conference stress, positive psychology and the national student survey. Psychology Teaching Review 2012; 18(2): 22-30.

16. Lazarus RS, Foklman S. Stress Apprasial and Copping, Springer Publishing, New York, 1984: 15.

17. Hewitt PL and Flett GL Perfectionism and learned resourcefulness in depression and self-esteem, Personality and Individual Differences, 1991; 12: 61-68.

18. Hollander MH. Perfectionism, Comprehensive Psychiatry, 1965; 6: 94-103.

19. Horney K. Nevrozlar ve İnsan Gelişimi, Öz Geliştirme Kavgası. (S. Budak, çev.). İstanbul Öteki Yayınları. 1975: 22.

20. Kalkan Dişbudak Ş. Öğretim Elemanlarının Mükemmeliyetçilik ile Tükenmişlik Düzeyleri Arasındaki İlişkinin Farklı Değişkenler Açısından İncelenmesi (Yüksek Lisans Tezi), Gaziantep Üniversitesi, Eğitim Bilimleri Enstitüsü, Eğitim Bilimleri Anabilim Dalı, 2016.

21. Karasar N. Bilimsel Araştırma Yöntemi, Nobel Yayın Dağıtım, Ankara, 2008: 68.

22. Karataş Z. Kontrol odağının yordayıcıları olarak saldırganlık ve çok boyutlu mükemmeliyetçilik, Ahi Evran Üniversitesi Kırşehir Eğitim Fakültesi Dergisi, 2012; 13(3): 245-260.

23. Kızılöz Başsayın A. Evli Bireylerde Mükemmeliyetçilik, Evlilik Uyumu ve Cinsel Doyum Arasındaki Ilişkinin Incelenmesi (Yüksek Lisans Tezi), Okan Üniversitesi, Sosyal Bilimler Enstitüsü, Klinik Psikoloji Anabilim Dalı, 2018.

24. Newbury-Birch D, Kamali F. Psychological stress, anxiety, depression, job satisfaction and personality characteristics in preregistration house officers. Postgrad MedJ, 2001; 77: 109111.

25. Oral M. Üniversite Öğrencilerinde Mükemmeliyetçi Kişilik Özelliği ve Yaşam Olaylarının Depresyon Belirtileriyle İlişkisi Depresyona Yatkınlık-Stres Modelinin İncelenmesi (Yüksek Lisans Tezi), Orta Doğu Teknik Üniversitesi, Sosyal Bilimler Enstitüsü, Psikoloji Anabilim Dalı,1999.

26. Rice KG, Ashby JS, Slaney RB. Self-Esteem as a mediator between perfectionism and depression, A Structural Equations Analysis, Journal of Counseling Pschology, 1998; 45(3): 304-314

27. Rimm SB. Keys to Parenting Gifted Child, Hauppauge, NY: Barron's Educational Series, 1994: 61-62 
28. Roedell WC. Vulnerabilities of highly gifted children, Roeper Review, 1984; 6(3): 127-130.

29. Siegle D, Schuler AA. Perfectionism Differences in Gifted Middle Students, Roeper Review, 2000: 39-44.

30. Slaney RB, Ashby J. Perfections study of a criterion group, Journal of Cunselling and Development, 1996; 74(4): 393-398.

31. Taş S. Düzce Üniversitesi Araştırma ve Uygulama Hastanesi Hemşirelerinde Psikolojik Dayanıklılık, Depresyon ve Algılanan Stresin Değerlendirilmesi (Yüksek Lisans Tezi), Düzce Üniversitesi, Sağlık Bilimleri Enstitüsü, Halk Sağlığı Anabilim Dalı, 2013.

32. Tozzi F, Aggen SH, Neale BM, Anderson CB, Mazzeo SE, Neale MC, Bulik CM. Thestructure of perfectionism a twin study, Behavior Genetics, 2004; 34(5): 483-494.
33. Uyanık S. Üstün Yetenekli Çocuklarda Mükemmeliyetçilik, Yalnızlık ve Kendine Saygı Düzeyinin Sınav Kaygısı Üzerindeki Etkileri (Yüksek Lisans Tezi), Uludağ Üniversitesi, Sosyal Bilimler Enstitüsü, Psikolojik Danışmanlık ve Rehberlik Bilim Dalı, 2007.

34. Wu T, Wei M. Perfectionism and negative mood the mediating roles of validation from others versus self, Journal of Counseling Psychology, 2008; 55(2): 276-288.

35. Yıldız M. Banka Çalışanlarında Stres Algisı ve Ruhsal Durum Arasındaki İlişkinin Araştırılması (Yüksek Lisans Tezi), Işık Üniversitesi, Sosyal Bilimler Enstitüsü, Klinik Psikoloji Bilim Dalı, 2017. 